\title{
A Sublimidade de Sião em Jl 4,15 -17
}

Orientador: Leonardo Agostini Fernandes

Mestrando: Antonio Marcos dos Santos

Área de Concentração: Teologia Bíblica

Linha de Pesquisa: Análise e Interpretação de Textos do Antigo e Novo Testamento

O tema da sublimidade de Sião em J1 4,15-17 revela uma imagem de YHWH que zela, carinhosamente, pelo seu povo. Diante das calamidades naturais e bélicas, a experiência da relação entre o povo de Judá-Jerusalém e YHWH faz despertar a consciência de que a fé deve ser superior ao temor de um futuro incerto. O presente estudo chega à conclusão de que $\mathrm{Jl}$ 4,15-17 tem como pano de fundo teológico a tradição de Sião, porém com um enfoque teocêntrico. A sublimidade de Sião em Jl 4,15-17 está vinculada essencialmente com o tema do yôm YHWH e se desenvolve em paralelo a este. Tal relação implica uma unidade integral dos temas no livro. O yôm YHWH, presente em todos os capítulos do livro de Joel, se apresenta integralmente com sentido positivo e salvífico para Judá-Jerusalém. A sublimidade de Sião em J1 4,15-17 corrobora com este yôm, sendo um oráculo de salvação para o povo eleito. $\mathrm{O}$ texto revela ainda pontos de contato terminológicos e temáticos com o livro de Joel e com alguns livros do corpus dos Doze Profetas. O conceito teológico da tradição de Sião, por meio da predileção pelo povo eleito na Cidade Santa de Jerusalém, segundo a ótica do livro de Joel, marca um aspecto relevante da fé bíblica vetero-testamentária.

Palavras-chave: Teologia Bíblica; Exegese do AT; Literatura Profética; Livro de Joel, Sublimidade de Sião. 